\title{
L'ORDENACIÓ DEL TERRITORI DEL PAISS VALENCIÀ ABANS DE LA CONQUESTA, SEGONS IBN-AL-ABBAR (SEGLE XIII)
}

Por

MÍKEL DE EPALZA

El territori del País Valencià actual, abans de la conquesta cristiana de la primera meitat del segle XIII, tenia una ordenació política i administrativa que no es basava només en la distribució física dels espais. Les autoritats musulmanes, al llarg de més de cinc segles d'exercici del poder, havien configurat una jerarquia d'espais político-administratius. En aquest treball no s'estudiarà l'evolució d'aqueixa ordenació del territori actualment valencià, a l'època àrab, sinó que es presentarà el resultat d'aqueixa evolució de més de mig mil. lenni, en el moment mateix del canvi radical que va suposar la conquesta cristiana.

La documentació adduïda serà purament àrab, no pas la cristiana de la mateixa època, i solament la del moment de la conquesta, no pas d'èpoques anteriors a aqueixa primera meitat del XIII. És la que reflecteix I'historiador i polític valencià Ibn-Al-Abbar i que correspon a l'ordenació del territori valencià pel poder almohade, últim règim polític musulmà abans de la conquesta, instal.lat a la regió des d'aproximadament.1170 (1).

No és que d'altres documentacions siguen menyspreables. La documentació cristiana d'aqueix moment pot ser preciosa i, en molts aspectes,complementària, però planteja uns problemes de distorsions de la realitat de l'època, amb actuals discussions científiques com més va més afinades sobre la seua utilització com a font per al coneixement d'aqueixa realitat imme-

(1) Per a una visió general del període, vegen M. J. RUBIERA - M. de EPALZA, Xătiva musulmana (segles VIII-XIII), Xàtiva, 1987, pp. 93-104. 
diatament anterior a la conquesta. D'altra banda, els textos àrabs plantegen cadascun problemes propis, amb fiabilitat diferent segons el tipus de text (geogràfic, cronístic, etc.) segons l'època de la seua redacció (amb utilització pels autors de fonts d'altres èpoques anteriors) i segons el lloc de redacció (els autors orientals utilitzen una nomenclatura pròpia, que no sempre coincideix amb la usual a Al-Andalus). D'ací la necessitat d'una crítica textual de cada autor en cada època, abans de fer síntesi en què es combinen les dades. És el que farem ací amb les informacions d'lbn-Al-Abbar en les seues obres històrico-literàries o biografies de savis que han nascut o viscut a la regió valenciana, dels seus mestres i de literats de diverses èpoques, les antologies poètiques dels quals presenta (2).

Ibn-Al-Abbar de València (1199-1260), de família originària d'Onda, és sens dubte el personatge polític i literari més important de la València precristiana (3). Com a escriptor, és autor d'una valuosa antologia o divan de la seua poesia, on destaquen els poemes a la pèrdua de València, especialment amb l'emotiva cassida que va recitar davant el sobirà de Tunísia a l'am-

(2) Les sigles de les obres i edicions biogràfiques d'lbn-Al-Abbar, amb la numeració per biografies i no pas per pàgines lamb excepció d'AAl, són:

AA - Al-Muqtadả min kitāb Tuhfat al-Qādim, ed. Alfredo Bustanì, Al-Mashreq. Beirut, 41, 1947, Seguim la 2. " edició, Ibrāhīm Al-Abyärī, El Caire, 1958, 207 pp. 1104 biografies, resum de I'obra d'lbn-Al-Abbar, feta per Al-Balfiqi del segle XIV, de Valefique (Aimería), encara que la seua família era de Xarq-Al-Andalus, segons Ibn-Al-Abbar MU-86 i MU-89.

AGP - Maximiliano ALARCÓN - Ảngel GONZÁLEZ PALENCIA «Apéndice a la edición Codera de la "Tecmila» de Aben Al-Abbar», Miscelánea de estudios y textos árabes, Madrid, 1915, pp. 145-690 (biografies 2.1532.982, amb afegits a les biografies de l'edició de Codera, CO).

CA - Takmila, ed. El Cairo, vol. I, 1955/1375 H., 351 pp. (biografies 1-1292), vol. II, 1956/1375 H., pp. 468-944 (biografies 1293-2188i).

CO-Takmila, ed. Francisco Codera y Zaydín, Complementum libri Assilah. Madrid, vol. 1, 1887, $416 \mathrm{pp.}$ (biograties 1-1185), vol. II, 1889, pp. XIV, 414-963 (biografies 1 186-2152).

HS - Al-Hulla As-Siyarā', ed. Husain Mu'nis, El Caire, vol. I, 1963, 312 pp. (111 biografies), vol. II, 1964, $480 \mathrm{pp}$. (biografies $112-216$ ).

MU - Mucjam, ed. Francisco Codera y Zaydín, Almôcham (Dictionarium ordine alphabetico de discipulis Abu Ali Assadafi ab Aben Al-Abbar, Madrid, 1886, XIX-368 pp. (315 biografies).

SA - Ictāb al-kuttāb, ed. Sālih Al-Axtar, Damasc, 1961/1380 H., 327 pp. (biografies 1-75) (Aquest llibre interessa poc per a aquest treball, perquè hi ha poques biografies d'Al-Andalus i només 5 estan relacionades amb la regió valenciana: SA-57 SA-61, SA-66, SA-68, SA-751.

(3) Ja féu veure la importància d'Ibn-Al-Abbar com a historiador el valencià Francesc PONS BOIGUES, Ensayo bio-bibliográfico sobre los historiadores y geógrafos arábigo-españoles, Madrid, 1898 (reimpressió Amsterdam 1972) il'acadèmic Eduardo SAAVEDRA, «Informe sobre la Técmila de Abén Alabar», El Archivo, Dénia, II, 1887-1888, 167. De l'abundosa bibliografia sobre Ibn-Al-Abbar, podem indicar A. BELMohamed BENCHENEB, "La préface d'Ibn Al-Abbar à sa Takmila as-sila», Revue Africaine, París, núm. 294, 1918, 306-335; I'article sobre una obra seua religiosa d'Ahmad GHEDIRA, "Un traité inédit d'Ibn Al-Abbar à tendance chiite», Al-Andalus, Madrid-Granada, XIII, 1957, 30-54, i dos llibres monogràfics en àrab ${ }^{\mathrm{C}} \mathrm{Abd}$ Al-cAz̄̄z IBN 'ABD AL-MAJID , Ibn Al-Abbär. Hayātu-hu wa-kutubu-hu, Tetuán, 1954, i 'Abd Allāh TABBAc, Ibn Al-Abbăr. Kitãb hullat as-siyarā', Beirut, 1962 itesi doctoral defensada a la Universitat de Madrid en 1956 i traduĩda a l'àrab). Dos bons treballs recents: María Jesús VIGUERA, «Los Fāțimies de Ifrīgiya en el Kitāb al-Hulla de lbn Al-Abbār de Valencian, Sharq Al-Andalus. Estudios Árabes, Alacant, 2, 1985, 29-37, i María Luisa ÁVILA, "El método historiográfico de Ibn al-Abbār", Estudios onomástico-biográficos de Al-Andalus, Madrid, 1988, 555-583. 
baixada que presidia per tal de demanar-li ajut per a la ciutat assetjada (4). També és autor d'antologies d'altres poetes, generalment d'Al-Andalus (5). Com a historiador, és famós per les seues biobibliografies d'autors d'AlAndalus, que són les que utilitzarem principalment per a l'estudi de l'ordenació territorial valenciana de la seua època (6). Com a polític, tenia un profund coneixement de tots els territoris sota sobirania musulmana d'Al-Andalus (havia viatjat fins a Sevilla i Badajoz) i especialment dels territoris dependents de València, on va tenir càrrecs públics diversos (cadi o "governador civil» a Dénia, d'altres magistratures a València i Morvedre) i va ésser alt funcionari dels governants de València $i$, després del desterrament consegüent a l'ocupació cristiana de 1238, de Bugia (actual Béjaïa) i finalment de la cort de Tunísia on va morir, víctima d'intrigues polítiques.

Els repertoris biobibliogràfics d'Ibn-Al-Abbar han estat sempre molt estimats per la seua toponímia o la seua abundància de noms de lloc (7). Mentre n'esperen els promesos repertoris exhaustius - ara informatitzats - (8), farem una prospecció, a partir dels textos editats, no pas per a estudiar-los exhaustivament, sinó per a esbossar l'ordenació territorial valenciana. Per a la qual cosa ens basarem en la "qualificació" que tenen aqueixos noms de lloc en lbn-Al-Abbar i la «jerarquització» dels territoris que això suposa, des del punt de vista politico-administratiu (algunes vegades mencionarem els topdnims inclosos en una nisba o nom personal o familiar d'origen - per exemple, Al-Qirbiliânî de Qirbiliân, Crevillent-), encara que no supose una qualificació del nom del lloc d'origen).

Aqueixos qualificatius - analitzats a l'apartat següent - tenen dues característiques que els fan particularment fiables per al proposit d'aquest estudi. D'una banda segueixen un sistema constant i perfectament rigorós (9). De l'altra, no tenen cap pretensió sistemàtica, ja que Ibn-Al-Abbar en cap moment no vol presentar una ordenació territorial, la qual cosa l'hagués portat - com a molts geògrafs àrabs - a utilitzar documentació d'èpoques diferents i a fer anacronismes o concordances distorsionants (10).

(4) Abd As-Salām HARRAS, "El diván de Ibn Al-Abbārn, Revista de la Universidad de Madrid, Madrid, XV, 1966,57-60, resum de tesi doctoral, el text de la qual s'edità en àrab Divăn Ibn Al-Abbār, Tunis, 1986.

- Sobre els poemes a la caiguda de València vegen María Jesús RUBIERA, "La conquesta de València per Jaume l com a tema literari en un testimoni de l'esdeveniment: Ibn Al-Abbar de Valèncian, L'Aiquadolc, Dénia, 7, 1988, 33-44.

(5) Vegen AA, HS, SA i A. A. AT-TABBAc, o.C.

(6) Vegen AGP, CA, CO i MU.

(7) Només mencionarem els noms dels principals investigadors que han utilitzat aqueixes obres per estudis toponimics: Codera, Ribera, Seybold, Mones, Sanchis Guarner, Coromines, Guichard, Vallvé, C. Barceló, Rubiera.

18) M. MEOUAK, "La Takmila d'Ibn Al-Abbār. Notes et observation à propos de ses éditions», Revue de I'Occident Musuiman et de la Méditerranée, Aix-en Provence, 40/2, 1985, 143-146, presenta un projecte francés per posar l'onomàstica valenciana de la Takmila d'lbn-Al-Abbar en ordinador.

(9) Només he trobat tres uirregularitatsn: diu que València és un àmal, del qual depenen Llíria i Sogorb CO 723 o Ábixa i Morvedre, CA-202 quan sempre diu que són amals dependents de València (crec que és mala transcripció del dual) i Alacant i Oriola de l'àmal de Múrcia CO-1594 (també un cas de dual). Hi ha algun cas més en AA, text que no és d'tbn-Al-Abbar directament, sinó un resum fet per un d'Almeria, poc rigorós i que desconeixia la situació valenciana: és una contraprova del rigor d'lbn Al-Abbar.

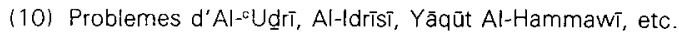


Ibn-Al-Abbar menciona els llocs i els qualifica a partir del seu coneixement directe, amb l'única finalitat de situar-hi els personatges biografiats i lluns activitats. Així, al seu coneixement summament autoritzat, com a alt càrrec de l'administració valenciana, s'afegeix la denominació directa i pragmàtica dels noms de lloc i la seua qualificació, tal com es coneixien al seu temps, a mitjans del segle XIII, ja que va iniciar els seus repertoris biobibliogràfics abans del seu exili de 1238 i en va prosseguir la redació a Bugia i Tunis, on havia de precisar un poc més - però també directament - la situació dels llocs valencians, per a uns lectors allunyats de la realitat del Xarc-Al-Andalus ("Orient de la Península Ibèrica àrab») .

Sols s'estudiarà, doncs, aqueix aspecte polític d'ordenació territorial (11), sense pretendre d'ésser exhaustius, perquè alguns topònims presenten dificultats d'identificació o de localització i perquè evidentment Ibn-Al-Abbar no esmenta més que aquells llocs relacionats amb uns quants centenars de personatges que van nàixer o viure a territori valencià. Si a certs llocs no va haver savis o no els esmenta, els llocs no apareixen. D'altra banda, quan alguns llocs només apareixen una vegada, cal ser conscients de la precarietat de la dada.

Tampoc no s'hi tractarà del problema crític de les edicions, ni de la duplicació de les biografies per a un mateix personatge, ni tampoc de la identificació de tots els topònims que no han estat fefaentment identificats pels que ens han precedit (hi aporte alguna identificació o correcció nova, de passada, perquè no és aquesta la finalitat d'aquest treball).

Amb aquestes limitacionos metodològiques, s'estudiarà:

1r. la terminologia de les localitzacions en Ibn-Al-Abbar.

$2 \mathrm{rd}$. les poblacions dependents de Múrcia.

$3 r$. les poblacions dependents de Dénia.

4rt. les poblacions dependents de Xàtiva.

$5 e ́$. les poblacions dependents de València.

$6 e ́$. les zones frontereres o militars, enfront de territoris cristians.

7é. I'ordenació judicial del territori valencià.

L'esquema que es presenta ací podrà enriquir-se amb algun topònim nou, fruit de noves identificacions, localitzacions o noves edicions de manuscrits. Però bàsicament correspon a les categories i esquemes d'ordenació del territori en terres valencianes d'època àrab, just abans la conquesta.

Aquest treball s'insereix, amb les seues limitacions, en el procés de donar a conéixer millor les característiques urbanes en tots els àmbits de la societat musulmana, especialment a València. Es veurà així que, al segle XIII

(11) Els antecedents més importants, encara que centrats sobretot en el segle $X, i$ a tot Al-Andalus, són H. MONES, "La diyisión político-administrativa de la España musulmana", Revista del Instituto Egipcio de Estudios islámicos en Madrid. Madrid, V, 1957, 79-183, i J. VALLVE, La división territorial en la España musulmana, Madrid, 1986. 
i segurament des de sempre, eren les ciutats les que configuraven tot l'espai polític dels territoris de Xarc-Al-Andalus, del País Valencià actual (12).

També es veurà, als capítols regionals següents, que les demarcacions territorials no corresponen enterament als límits autonòmics actuals, ni en la seua part meridional - dependent de Múrcia - ni septentrional, on la jurisdicció valenciana entrava en territoris aragonesos o havia heretat de territoris tortosins, en caure aquesta ciutat i les terres de la conca baixa de l'Ebre a les mans de cristians.

Finalment cal advertir, en aquestes observacions prèvies, que aquesta estructura d'ordenació havia estat advertida ja per l'arabista valencià Julià Ribera i Tarragó, al final de la seua vida i des del seu retir de Carcaixent: és "l'administració i ordre de les ciutats» dels àrabs valencians, l'estudi dels quals pretenia impulsar (13).

Els termes en cursiva indiquen la transcripció del text o de l'escriptura àrab, però de cap manera la pronunciació d'aqueixa paraula. Per això van acompanyats del terme - nom propi o nom comú - catalanitzat (14).

\section{La terminologia de les localitzacions, en Ibn-Al-Abbar}

Ja s'ha dit que aqueix historiador esmenta els topònims i els qualifica sols en funció de la localització dels seus biografiats i dels seus càrrecs o activitats. Es poden detectar així diferents sèries de qualificatius de topònims.

La primera és d'ordre político-administratiu, al voltant del terme àmal, plural amals (en àrab ${ }^{c} a m a l$, plural $a^{c} m / l a l$ ) que podríem traduir per "capital comarcal», ja que engloba alhora el concepte de «ciutat amb capitalitat jurisdiccional» i el d'una "població comarcal», més que no directament un territori. Cal recordar que el dret musulmà, a diferència del romano-feudal, considera prioritàriament les relacions d'autoritat i de jurisdicció en relació amb els grups de persones més que no en relació amb els territoris en els quals viuen (matisació complexa, que no pot desenvolupar-se ací). Segons lbn-AlAbbar, confirmat per d'altres fonts que no són tan rigorosament sistemàtiques (15), l'àmal és - per a l'època almohade del segle XIII - la unitat admi-

(12) Vegeu insistència en aqueix aspecte en M. J. RUBIERA - M. de EPALZA, Xàtiva ... pp. 19, 34-37, 127144 i M. de EPALZA, "Precisiones sobre instituciones musulmanas de Baleares", $V$ Jornadas d'Estudis Historics Locals. Les Illes Orientals d'Al-Andalus i les seves relacions amb Sharq Al-Andalus, Magrib i Europa Cristiana (ss. VIII-XIII), Palma de Mallorca, 1987, 73-89.

(13) J. RIBERA i TARRAGO, "Prólogo al 'Repartiment de Valencia'», Opúsculos Dispersos, Tetuán, 1952. p. 63.

114) Sobre la utilitat de no usar transcripcions de l'àrab més que quan es vol reproduir el text escrit en àrab i si no usar el nom actual, generalment més proper a la pronúncia dels àrabs, vegeu M. de EPALZA, «Precisiones...", pp. 74-75, i S. MARTÍNEZ-TERCERO - M. de EPALZA, "Sobre la arabización de los nombres de las Islas Baleares: Maiorica, Minorica, Ebusa-Ebisa, Furmentera-Formenteran, Les IIIes..., 173-179.

(15) Veg. G. 'ABD AL KARIM, Terminología geográfico-administrativa e historia político-cultural de AlAndalus en el "Mucyam Al-Buldãn" de Yãqüt, Sevilla, 1972, per a un autor oriental. Exemple d'utilització d'una sola font i del seu lèxic M. de EPALZA, "Estudio del texto de Al-Idrisi sobre Alicanten, Sharq 
nistrativa fonamental a Al-Andalus, centrada en la capital comarcal que li dóna el nom. Són els "amals governamentals o estatals» (acmâl makhzumiyya), que cita incidentalment Ibn-Al-Abbar HS-142 quan parla de «la instal.lació de l'estat o règim dels almoràvits" (ihtilal dawla al-mulaththimîna).

Però els amals depenen d'una unitat político-administrativa superior: les metròpolis o ciutats capitalines. Ibn-Al-Abbar no les sol aplicar un terme qualificatiu determinat: s'acontenta a mencionar que d'elles depenen aquests amals. A l'actual territori valencià hi ha quatre ciutats que tenen aqueixa categoria: València, Xàtiva, Dénia i Múrcia.

A València se l'anomena de vegades hâḍira ("capital»)HS-128 o haḍra Balansiya MU-105, que podria significar també «de la banda de». Aquests mateixos qualificatius s'apliquen a d'altres importants capitals regionals, com Badajoz HS-128 o Tunis (HS-146 HS-266 CO-1217). Potser és una expressió per oposar la ciutat a les seues rodalies (madîna-ahwâz) com en el cas de Fes HS-49. En un text sembla oposar la madîna de València i a haḍra de Còrdova HS-8 HS-6, evidentment més important per als historiadors andalusins. En altres contextos, sembla que es vulga recalcar que un estudiós tingué una docència no a la regió de València sinó al centre mateix de la ciutat AGP-2373. Per aquest motiu es menciona la "ciutat" de València (madîna Balansiya) CA-903 CO-52 quan el nomenament d'un cadi CA-903 o arran d'uns estudis CA-704 o d'un encontre CO-52. Però el que és molt clar és que els amals ho són en funció de la seua dependència directa i orgànica d'aqueixes metròpolis. Un text aillat d'Ibn-Al-Abbar expressa aqueixa relació orgànica de les metròpolis i els seus amals: "un dels amals de la senyoria de Toledo" (min $a^{c}$ mâl hadra Tulaytula SA-67). En uns altres nivells - polítics però no administratius - es pot parlar de l'alcàsser o centre político-militar de València (qașr HS-135) o del "poble de València" (ahl Balansiya), com a subjecte d'uns avalots HS-145.

En la terminologia d'Ibn-Al-Abbar, se sol mencionar aqueixa dependència jurisdiccional amb dues fórmules, sempre relacionades amb topònims de ciutats (16): «lloc $X$, àmal $d^{\prime} Y$ " (makânun camal makânin) i «loc $X$, un dels amals d'Y» (makânun min acmâl makânin).

D'altra banda, I'àmal és una unitat jurisdiccional que engloba diversos nuclis de població. Són sobretot les alqueries (qarya, plural qurà), que es mencionen generalment en relació amb l'àmal del qual depenen o en el qual se

Al-Andalus. Estudios Árabes, Alacant, 2, 1985, 215-232. Sobre l'origen dels variats sentits de cāmil (àmil o governador d'un àmal), veure Encyclopédie de l'Islam, 2. ${ }^{a}$ ed. 1, 447-448 (en el Corà, IX, 60, ja seria «recol.lector d'impostors»l.

(16) En Ibn Al-Abbar, les ciutats són sempre les referències; de vegades un accident geogràfic (Rugat "a l'oest del congost’ CA-2027 i la muntanya d'Amr AGP-2298). En canvi, l'oriental Yacut Al-Hámawi parla d'Altea com formant part del "Nàzar de la Muntanya" (G. 'ABD AL-KARIM, "Yacut. La España musulmana en la obra de Yaqut (siglos XII-XIII). Repertorio enciclopédico de ciudades, castillos y lugares de Al-Andalus extraídos de Múcyam al-buldan (Diccionario de los países). Traducción», Cuadernos de Historia del Islam, Granada, 6, 1974, p. 87, la qual cosa pot ser certa però no correspon al concepte de l'andalusí Ibn-Al-Abbar, per a qui l'àmal està sempre vinculat a una ciutat que és la seua capital. 
situen. Alguna vegada es qualifiquen aqueixos nuclis menors de població com a «lloc» (mawdic) CA-70, també en relació amb l'àmal a què pertanyen. Crec que hem demostrat en front de l'opinió de Pierre Guichard, que les qarya - en època musulmana - signifiquen mers nuclis de població, sense la més petita càrrega semàntica directa en relació amb la propietat col.lectiva de la terra i menys encara amb el pretés binomi alqueria - rafal (raal), propietat col.lectiva - propietat personal (17). Els rafals (rahal) no apareixen per a res en Ibn-Al-Abbar, així com tampoc el terme «aldea» (en àrab daica), que sí té clara connotació de "propietat estatal arrendada» (18). En canvi la qualificació d' «alqueria» o «poble» (qarya) és molt freqüent per designar un lloc menor dependent d'una ciutat capital comarcal d'un àmal.

La paraula balad, que podria designar també «poble», sols s'usa en IbnAl-Abbar en el sentit de "patria d'u, la seua ciutat natal, la terra", sempre amb possessiu (baladu-hu en CA-420, CO-1593, MU-77 i pàssim), no com a upoble, llogaret, població menorn. El seu plural bilâd sols s'empra en expressions generals: "per terres de Xarc-Al-Andalus» CA-489.

Es veu, doncs, en la qualificació dels llocs d'Ibn-Al-Abbar, una clara piràmide administrativa a tres nivells: $1 r$ les metròpclis o capitals; $2 n$ els amals o capitals comarcals; $3^{r}$ els nuclis inferiors de població, com les alqueries.

Sembla que el terme ${ }^{c} a m a l$ té una càrrega semàntica també militar, en el sentit que les ciutats que són caps d'amals tenen una situació estratègica important $i$ bones fortificacions. Es molt probable que la reforma administrativa d'almohades i almoràvits, reflectida als amals, corresponga a un desig de reforçar el conjunt del territori d'Al-Andalus, davant el perill cristià des de finals del segle XI. De fet els "governadors" o àmils ('âmil) dels amals tenen caràcter militar —en part, també fiscal- i mai no apareixen entre els biografiats d'Ibn-Al-Abbar (amb l'única excepció del conegut governador de Menorca Saïd Ibn-Uthman HS-170), perquè serien militars, d'origen magrebí en època almohade, personatges que no tenien la cultura erudita dels que interessaven a l'historiador valencià. En canvi sí que apareixen nombrossos càrrecs administratius i judicials relacionats amb l' "administració civil» (cadis, kàtibes, docents, predicadors, etc.) en el complex entramat de qual no entrarem en aquest treball, a pesar de la seua íntima relació amb l'ordenació del territori valencià.

La segona sòrie de qualificatius que revela una ordenació políticoadministrativa gira al voltant del terme cora (en àrab kûra, plura kuwar), que apareix qualificant algunes de les ciutats de la regió, concretament Elx, Llíria i Sogorb, plantejant alguns problems.

El primer problema resideix en la utilització tradicional del terme cora, en àrab. Engloba regions molt amples: en època del califat, hi havia a la nostra

(17) Veg. M. J. RUBIERA MATA, "Rafals y raales; ravals y arrabales; reals y reales", Shara Al-Andalus. Estudios Arabes, Alacant, 1, 1984, 117-122, i M. J. RUBIERA - M. de EPALZA, Xàtiva..., p. 18.

(18) M. J. RUBIERA - M. de EPALZA, Xàtiva..., p. 60. 
regió dues cores, la de Múrcia i la de València (de vegades, també Xàtiva) (19). ¿Com s'aplicarà aquest terme, al segle XIII, a districtes evidentment menors, com Elx, Llíria i Sogorb? Un segon problema resideix en la duplicació de termes, amb cora i àmal: tant Elx, como Llíria o Sogorb són cores però també apareixen nombroses vegades com amals respectivament de Múrcia (Elx) i València (Llíria i Sogorb). ¿Quina diferència hi ha entre aquests dos termes administratius? Un tercer problema s'afegeix als anteriors: ¿per què no es menciona aquesta categoria de jurisdicció, dependent de les metròpolis, per d'altres poblacions valencianes que són amals com elles?

Aquests nivells de problemes - que crec ser el primer a plantejar- tenen fàcil solució si es considera que les cores representen una jurisdicció judicial, segons Ibn-Al-Abbar. Seria al segle XIII una xarxa de seus d'una magistratura comarcal, també dependents de les metròpolis. Aixi s'explica la doble denominación d'àmal i de cora per a certes ciutats comarcals. De fet, Ibn-Al-Abbar en les seues biografies empra «àmal» per a situar l'origen, naixement o estada d'un dels seus biografiats, i usa - molt menys - "cora" quan parla de la destínació o nomenament d'un magistrat (per exemple, CA-2117): «fou nomenat per a exercir el càrrec de cadi de tal cora» (wuliya qidâ' kûra makânin) o «fou nomenat per a exercir el càrrec de cadi de diverses cores de Xarc-Al-Andalus» (wuliya qiḍâ' ba ${ }^{c} \underline{d}$ kuwar Xarq Al-Andalus). Açò explica també que es mencionen les cores en pocs casos i en ciutats petites: en les ciutats majors se suposa un tribunal i una jurisdicció judicial i es diu senzillament "fou nomenat per a exercir el càrrec de cadi de tal ciutat", sense especificar que és una cora. Açò evidentment, redueix un poc el nostre coneixement de la xarxa administrativa dels amals, segons Ibn-Al-Abbar i la realitat de l'ordenació territorial valenciana del segle XIII (vegeu capítol 7é d'aquest treball per ampliar l'estudi d'aqueixa xarxa judicial).

Un altra sèrie de qualificatius que aplica Ibn-Al-Abbar a llocs valencians formen una ordenació territorial que podríem anomenar militar: les zones de frontera (el thagr, plural thugûr que convindria catalanitzar en thagr $i$ thagrs). Són, segons Ibn-Al-Abbar i la situació geopolítica del seu temps, les zones de Requena, Alpont, Culla, Xivert, Onda, Peñíscola i Abixa, com s'etudiarà al capítol 6é d'aquest treball. Com a qualificatiu militar s'utilitzen també els termes de "castell o alcalà» (qalca, plural qilấc) per a Alpont CA-1083, Xèrica CA-1200 i Xivert, i també els de «castell» o hișn (plural husun) per a Aipont AGP-2206 CO-1173, Almâna prop Xàtiva CA-438, Montornés HS-145. El terme de "costera, altura» ('aqaba $i$ els seus derivats) pot tenir sentit estratègic i militar, però és originàriament un terme d'accident físic, aplicat per |bn-A|Abbar a Morvedre i Abixa CA-1204 CO-553 (20). S'ampliarà aquesta referència a l'ordenació d'aqueixos territoris militars de les fronteres amb els cristians al capitol 6é.

(19) Idem., p. 17-19

(20) Veg. E. TERÉS, "Al*Aqaba. Notas de toponimia hispanoáraben, Al-Andalus, Madrid, 43, 1978, $369-403$ 
Una quarta categoria o quart grup d'expressions qualificatives no té referència a un ordenament polític del territori valencià, com els tres grups anteriors. Són simples referències geogràfiques, encara que sempre en relació amb les ciutats. Aquest grup indica, d'una banda, que Ibn-Al-Abbar -com d'altres textos àrabs medievals - barreja qualificatius d'índole diversa, que no hauriem actualment d'unificar arbitràriamente o sistemàticament, però també confirma d'altra banda, que l'historiador valencià l'únic que pretén és assenyalar la localització, utilitzant-hi qualsevol categoria de referència espacial, encara que sempre en relació amb un context urbà, de nuclis importants de població.

S'han reunit en aquest grup a) els conceptes geogràfics d'orientació (nord, sud, est, oest); b) el terme jiha i el seu plural jihât ("cap a», "en direcció a", "devers"); c) el terme nâhiya, plural nawâhî (urodalia», "voltants»). Tots ells són termes molt utilitzats per lbn-Al-Abbar, especialment per referència a València, la qual cosa pot explicar-se per una gran densitat de població dispersa al seu voltant, on aquestes fórmules vagues supleixen una localització precisa difícil d'expressar.

Les expressions "al nord de» (bi-jawf, per a una alqueria de Xàtiva CA-510 i per a Sarrión al nord de València CO-179), "al sud de" (qib/î CA-2027 MU-202), "a l'est de" (fî xarqî, que segons Ribera significaria la riba esquerra del riu Guadalaviar o Túria (21). La costa septentrional de València i Castelló actuals és xarqî CA-420), "a l'oest de" (fî garbî, generaiment de València, com Silla, Picassent, etc.) s'usen sobretot per indicar la situació d'alqueries que depenen de València capital. No corresponen a l'orientació moderna, com explicà molt bé Ribera: els àrabs tenien el sud (qiblî) cap a la Meca, és a dir cap al mar, i les altres direccions lògicament desviades segons aquest criteri. Aquesta orientació geogràfica, dominada per la religió i sense connotacions administratives, mostra un aspecte important de la distribució dels espais i dels temps regits per l'Islam (22).

L'expressió jiha i el seu plural jihât signifiquen generalmente direcció i per això es poden traduir amb el seu sentit primari de "cap a», "en direcció a», "els voltants de", però és molt possible que tingués un aspecte més substantiu en Ibn-Al-Abbar, com els actuals sentits que ha pres la paraula en àrab: "comarca", "districte", "barri». Parla de la jiha de Requena, CA-813, però sobretot de les jihât de Xàtiva Ion se situa una vegada Cocentaina, que és un altre districte judicial i administratiu, que depén de Dénia, per la qual cosa pense que aqueixos jihât són purament una localització geogràfica) i de València (en els jihât de la qual diu que és Sogorb, que en realitat és un dels seus amals, bastant allunyat). S'usa aquesta qualificació per a nomenaments judicials («cadi

(21) "Las tierras de la huerta de Valencia en tiempos árabes se dividian en dos grandes porciones: las de la izquierda del Guadalaviar se llamaba Axarquía, y las de la derecha la Algarbian, com en aitres regions al voltant de grans ciutats d'Al-Andalus com Málaga i Sevilla (veg. J. RIBERA Y TARRAGO, "El Santón de Almusafes", Almanaque de "Las Provincias», Valencia, 1930, p. 219; Opúsculos Dispersos, Tetuán, 1952, 19-22)

122) M. J. RUBIERA - M. de EPALZA, Xàtiva..., págs. 117-144. 
en més d'un lloc de les jihât de Xàtiva" CA-184, "cadi en més d'una jiha de les jihât de Múrcia" CA-272, "cadi a Cocentaina i d'altres jihât llevantines" CA-1346), però també per a nomenaments de predicador, per a indicar lloc de naixenca i fins i tot amb una certa indeterminació de jurisdiccions, com s'ha dit. Per això, el més probable és que es tracte d'una simple referència geogràfica, en relació amb una ciutat i sense referència directa al seu territori administratiu.

Quasi el mateix pot afirmar-se en aquest sentit del terme nâhiya i el seu plural nawâhî: té alhora un sentit adverbial i substantiu, entre els significats en català $i$ en castellà d' "al voltant de» i d' "els voltants de». C. Barceló dóna un caràcter molt substantivat i específic a la paraula quan diu que "la ciutat que mantenia sota el seu control l'espai agrícola (nâhiya)», però afegeix de seguida, per a no accentuar un possible aspecte administratiu: "Aquesta també era la tesi de Lévi-Provençal, per a qui al-Andalus estava dividit en ciutats, no en cores, i tant aquestes com la nâhiya no tingueren mai valor oficial» (23). També és molt coneguda en la llengua àrab l'expressió, molt general, "de totes parts» (min kull nâhiya), també utilitzada per Ibn-Al-Abbar HS-34.

En els repertoris biogràfics, es mencionen alqueries de la nâhiya de Cullera, Llíria, Dénia i el "Mont d’Amr» (jabal 'Amr) "de la nâhiya de València CA-54. El plural s'usa sobretot per a València, insistint que té algunes nâhiya (bac d nawâhî, "alguna de les nâhiya de..." CA-2056) o que u fou nomenat predicador en algunes nawâhî de València CA-1477, peró també s'aplica a Onda ("de les nawâhî d'Onda" CO-781). La quasi equivalència de jiha-jihât i de nâhiya-nawâhî apareix sobretot en uns nomenaments de càrrecs de mesquites CA-2182 CO-833 CA-1360, però pot afirmar-se que ambdós termes es refereixen d'una manera general a una localització geogràfica de districtes menors.

El que sembla evident és que també aquesta terminologia indica abans de tot una localització geogràfica respecte a una ciutat, amb referència a una zona rural si voleu, però no administrativa, encara que tinga forma substantiva i puga traduir-se per "zona", "districte», "país", "banda", "part», però amb tots aquests significats al mateix temps.

Sols una vegada es menciona el terme de bâdiya, que a Al-Andalus no designa allò beduí sinó allò rural com oposat a allò urbà: "era originari del camp de València, encara que fou conegut amb el nom d'El Valencià", escriu Ibn-Al-Abbar, pot ser amb cert orgull de ser de la ciutat de València i no de la seua horta MU-38.

Una sola vegada apareix el terme juz' ("part», però també «districte» i fins i tot pot ser "partida"), referit a I'alqueria de Bâlima (probablement I'actual Palma de Gandia), en el juz' de Bairén CA-2066. El juz' (plural ajizâ') apareix molt com a unitat territorial (¿administrativa? ¿de producció? ¿fiscal?...) en els

(23) C. BARCELÓ TORRES, Toponímia aràbica del País Valencià. Alqueries i castells, Xàtiva, 1982, p. 42. 
repartiments baleàrics (24), però caldria fer moltes reserves sobre l'efectivitat i origen àrab (o barbaresc dels almoràvits) en aqueixos repartiments, tan influits per la terminologia dels conqueridors cristians encara que s'usen paraules àrabs (25). De tota manera, el terme juz', amb evident sentit d'espai dependent d'un camal, el de Bairén, està ací document en Ibn-Al-Abbar.

Finalment, dues referències geogràfiques àmplies afecten també el territori valencià, perquè hi és inclòs: "el Llevant d'Al-Andalus» i "la marca o marques orientals".

La demarcació Xarq Al-Andalus, "Orient o Llevant de la Península Ibèrica àrab», apareix molt sovint en Ibn-Al-Abbar. Conté tot el territori actualment valencià, però també part de Catalunya, Terol, Conca, Albacete i tota l'actual Comunitat Murciana (un originari de Silves «se'n va anar els amals de Xarq Al-Andalus" CA-2091). S'usa per indicar un origen vague, una localització múltiple, d'uns estudis CA-308, d'origen AGP-2536, d'estada o viatge AGP-2871 CA-2060. Origina cognoms o noms d'origen (Ax-Xarqî, "el de Xarq Al-Andalus» CA-1175 CO-524) i s'usa en fórmules generals: "viatjà per terres de Xarc-AlAndalus" (tajawwala bi-bilâd Xarq Al-Andalus) o venia gent a veure'l de tot Al-Andalus, "del Llevant $i$ del Ponent d'Al-Andalus" (min Xarq Al-Andalus waGarbi-hâ CO-750).

La demarcació Ath-Thagr Ax-Xarqî l'estudi de la qual es farà una mica més detingudament al capitol 6é d'aquest treball, designa en Ibn-Al-Abbar «la marca o les zones frontereres orientals», des de Daroca, Lleida i Tortosa, ja ocupades pels cristians al segle XIII, fins al nord de I'actual província de Castelló. Dóna també antropònims: Ath-Thagrî, "el de la zona fronterera de l'Islam», el Zegí o Tagarí MU-312 (26).

L'anàlisi i la classificació d'aquestes denominacions, la concreció de les quals al País Valencià es veurà als apartats següents, permet de comprendre com Ibn-Al-Abbar no té més finalitat en utilitzar-les que la de situar els llocs d'una manera coneguda per la majoria dels seus lectors del segle XIII. Si bé és veritat que és bastant rigorós i sistemàtic en les seues classificacions, n'usa també un variat registre, segons li semblen més útils per a la seua localització, per conegudes. Però la seua referència fonamental i pràcticament única és la referència a les ciutats o nuclis de població, siga com vulga la seua entitat; no apareixen noms de regions o zones que no siguen nuclis de població, menys les dues darreres mencionades, molt generals, d' "Orient d'Al-Andalus» i "zones frontereres llevantines".

(24) Veg. A. PUVEDA, "Sobre los distritos, las explotaciones y la toponimia clánica de Yābisa (Eivissa)", Sharq Al-Andalus. Estudios Árabes, Alacant, 1, 1984, 109-117.

(25) Veg. M. de EPALZA, "Precisiones...", pp. 8=-85; M. J. RUBIERA - M. de EPALZA; Els noms àrabs de Benidorm ila seua comarca, Benidorm, 1985, pp. 54-62; M. de EPALZA - M. J. RUBIERA, "Estat actual dels estudis de toponimia valenciana d'origen àrabn, Xé Col loqui General de la Societat d'Onomástica. Ter d'Onomàstica Valenciana, València, 1986, 420-426.

(26) Veg. estudi, referit particularment ala zona de la Vall de l'Ebre, en M. de EPALZA, «Tortosa, un Iloc estratègic a Al-Andalus», $D(T)$, Tortosa, 2, 1987, 13-15; "El Islam aragonés, un ísiam de frontera», Turiaso, Tarazona, VII, 1987, 9-21. 


\section{Les poblacions dependents de Múrcia}

Múrcia és, al segle XIII, una gran metròpoli àrab, amb nombroses relacions amb València, especialment com a conseqüència dels quasi quatre decennis del segie XII en els quals va dependre d'un mateix sobirà - $I b n S a^{c} d$ Ibn Mardanix, el rei Llop - i la seua família. Seguint Ibn-Al-Abbar, Múrcia tenia molts amals sota la seua jurisdicció (Cartagena, Mula, Yecla, Jumilla, Chinchilla, etc.) alguns d'ells en territoris dels límits meridionals de l'actual comunitat autònoma valenciana. Ens ocuparem únicament d'aquests últims.

En Ibn-Al-Abbar apareixen cinc amals valencians dependents de Múrcia: Oriola (Üryûla, ${ }^{\circ} a m a l$ Mursiya, min a ${ }^{c}$ mâl Mursiya), Elx (Alx o $\| x$, amb les mateixes dues fórmules, uàmal de Múrcia» AA (p. 76) Co-919 CO-1009, "un dels amals de Múrcia» MU-291 AA [p. 63 (27)], Alacant («àmal de Múrcia» CO-718) i Villena ("dels amals de Múrcia» CA-496). Callosa (Oalyûxa) apareix sols una vegada com «un dels amals de Múrcia» MU-132: és quasi segur que es tracta de Callosa de Segura, malgrat la proximitat a una altra capital d'àmal, Oriola.

D'Elx es diu que és "cora de Múrcia» i «una de les cores de Múrcia» (kûra Mursiya, min kuwar Mursiya). Aquesta referència explícita a una demarcació judicial no es fa en el cas de les altres quatre capitals comarcals d'amals, però pot suposar-se, com es veurà més endavant.

Sols apareixen demarcacions menors en antropònims, no en topònims amb qualificatius com "alqueria", "lloc", "castell", etc., com es veurà en amals dependents de Dénia, Xàtiva i València. Al-Qirbilyânî CA-1374 és originari de Crevillent (Qirbilyân), població molt esmentada en fonts àrabs després de la conquesta cristiana. Un Al-Qaștâlî «de família murciana» podria ser de Castalla, encara que aquest cognom o nom de família és de Cazalla i altres llocs homònims d'Al-Andalus: no consta que la comarca de Castalla dependés de Múrcia i no de Cocentaina-Dénia, encara que el biografiat (finat el 558/1162/3) estava molt lligat a la política d'Ibn-Saad-Ibn-Mardanix, sobirà de tota la zona MU-155 HS-167.

S'ha de repetir que Ibn-Al-Abbar no és exhaustiu: sols esmenta els llocs quan estan vinculats als seus biografiats. D'altra banda, és evident el seu major coneixement de la zona valenciana, encara que també estigué almenys tres vegades a Múrcia: en el seu viatge d'anada i tornada a Sevilla i en exiliarse de València a Tunis. Per això pogué haver algun àmal més en l'actual espai valencià, o uns bocins de territoris dependents dels amals murcians de Cartagena, Yecla o Jumilla, o, pel contrari, amb territoris actualment murcians dependents d'Oriola. Potser hi hagué un àmal que no produí intel.lectuals notables, al Vinalopó Mitjà, entre Alacant, Elx i Villena, però no sembla probable. Les comarques del sud de l'actual País Valencià apareixen així a mitjan

127) Una vegada diu que és "àmal de València» CA-1660, la qual cosa sembla una equivocació, l'origen de la qual pot ser múltipie. 


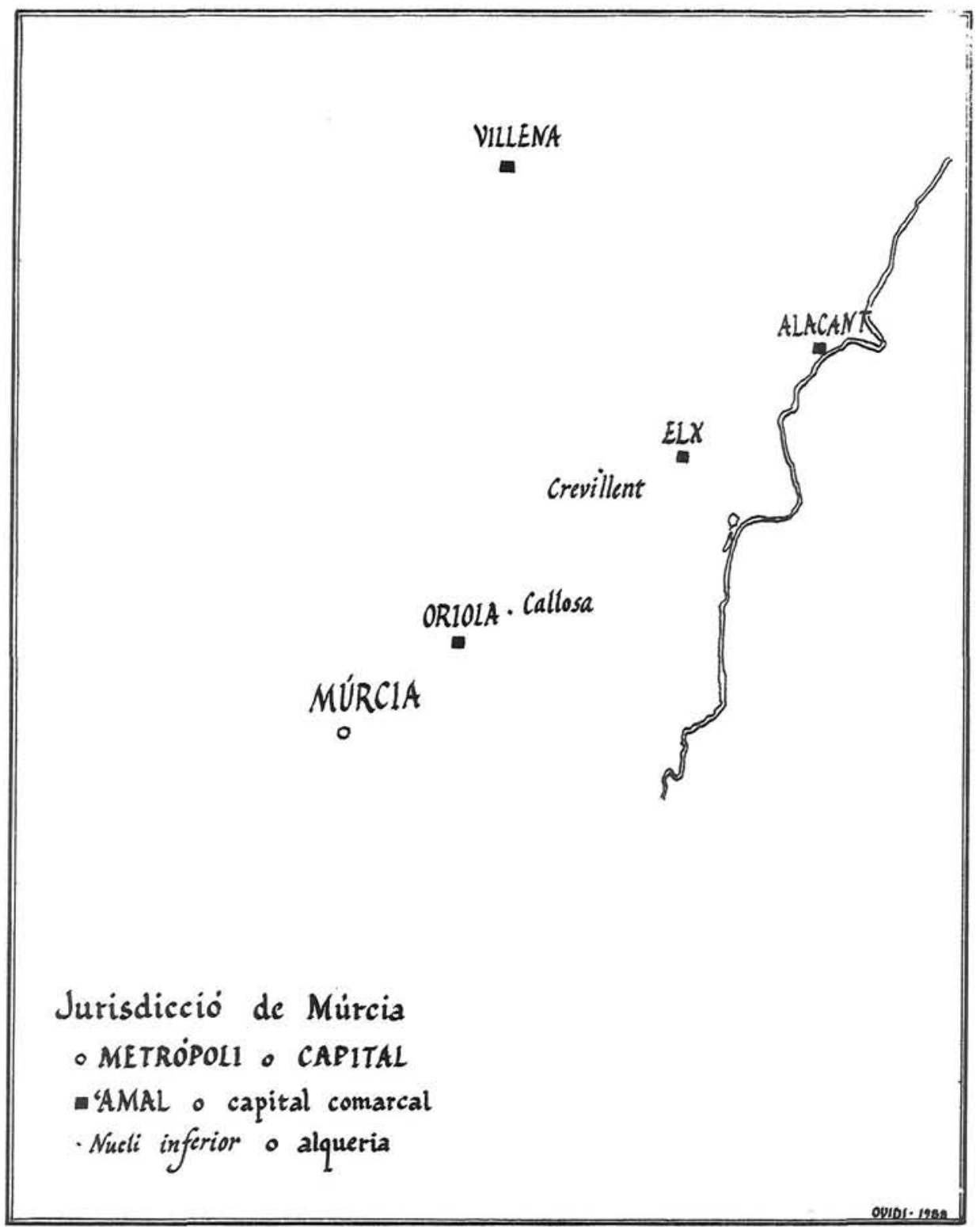


segle XIII, amb les quatre o cinc capitals comarcals, centres urbans d'amals político-militars i de cores judicials, dependents de la metròpoli murciana.

Als mapes annexos se situen aqueixes capitals i les poblacions menors. No es poden representar delimitacions territorials de cada jurisdicció, ni a partir d'lbn-Al-Abbar ni d'altres fonts àrabs o cristianes, mudes unes i deformandes d'altres sobre aquest particular. Però sí que es podrien trobar altres poblacions d'aquesta època gràcies a altres dades cronístiques àrabs (Asp, Așf, per exemple), en geògrafs (Petrer, Bitrîr, per exemple), per l'arqueologia i per la toponímia quan és inequívocament d'època àrab.

\section{Les poblacions dependents de Dénia (28)}

Dénia segueix sent, al segle XIII, una important metròpoli marinera i un centre intel. lectual on acudeixen estudiants i professors. El mateix Ibn-Al-Abbar tindrà a Dénia algun càrrec públic (cadi en 663/1235-6 CA-2117) i Dénia serà la primera etapa del seu exili, després de la caiguda de València.

La jurisdicció de Dénia arriba almenys a tres åmals: Cocentaina (Qusanțâniya MU-137 o Qustanțâniya CA-156 CO-2051 CO-507 CO-653, «àmal de Dénia», "per la banda de Dénia» min jiha Dâniya), Bairén (Bayrân, "àmal de Dénia» CA-1506 CO-862, "dels amals de Dénia» i l'àmal de Batrûxa o Pedrosa, patria d'un Ibn Qatâl CA-635 relacionat amb d'altres Banu Cadell «deniers» MU-60 AA (p. 18) que estarien relacionats amb la fortalesa de Benicadell, la qual cosa, situan Batrûxa en aqueixa zona, prop de Xàtiva (29).

Encara que no ho mencione Ibn-Al-Abbar i sí ho faça un geògraf oriental Yacut Al-Hámawi, hi hauria una demarcació "de la Muntanya», dependent de Dénia, a la qual pertanyeria Altea (30). La dada és heterogènia respecte a l'ordenació territorial d'Ibn-Al-Abbar (tots els seus amals porten el nom d'una ciutat i no d'una regió, "la muntanya") i, per les referències conegudes als Sid Bono de Benifato, la Vall de Guadalest, territori de la muntanya més proper a Altea, depenia jurídicament de l'àmal de Cocentaina (31). És un exemple de les dificultats de compaginar les diverses fonts àrabs, per la qual cosa s'ha preferit no incloure dades heterogènies en aquest ja prou llarg treball.

(28) Un precedent d'aquest capitol: J. RIBERA Y TARRAGÓ, "La província de Denia», El Archivo, Dénia, I, 1887, 251-254. Sobre els orígens de l'espai polític del regne taifal de Dénia en el segle Xl, vegeu M. J. RUBIERA MATA, La Taifa de Denia, Alacant, 1985, 1988, especialment el capítol If "Origenes del Reino de Denian.

(29) Veg. P. GUICHARD, «Un toponyme historique de l'ancienne kura de Tudmir: Benicadell», Murgetana, Múrcia, 45, 1976, 37-47.

30) Veg. supra, nota (16)

(31) Veg. J. BOSCH, "Notas de toponimia para la historia de Guadalest y su valle», Miscelánea de Estudios Árabes y Hebraicos, Granada, XIV-XV, 1965-1966, 47-75, Sharq Al-Andalus. Estudios Árabes, Alacant, 201-230; M. I. CALERO SECALL, "Los Banū Sĩd Būna", Shara Al-Andalus. Estudios Árabes, Ala cant, 4, 1987. 37-44; M. de EPALZA, "La tumba de un Santo Musulmán en Benifato", Alcoy, Alcoi, 1988, 164-165 i F. FRANCO SÁNCHEZ, "La familia de los Síd Bono: unos Santos árabes de Guadalest" Alcoy, Alcoi, 1988, 162-163. 


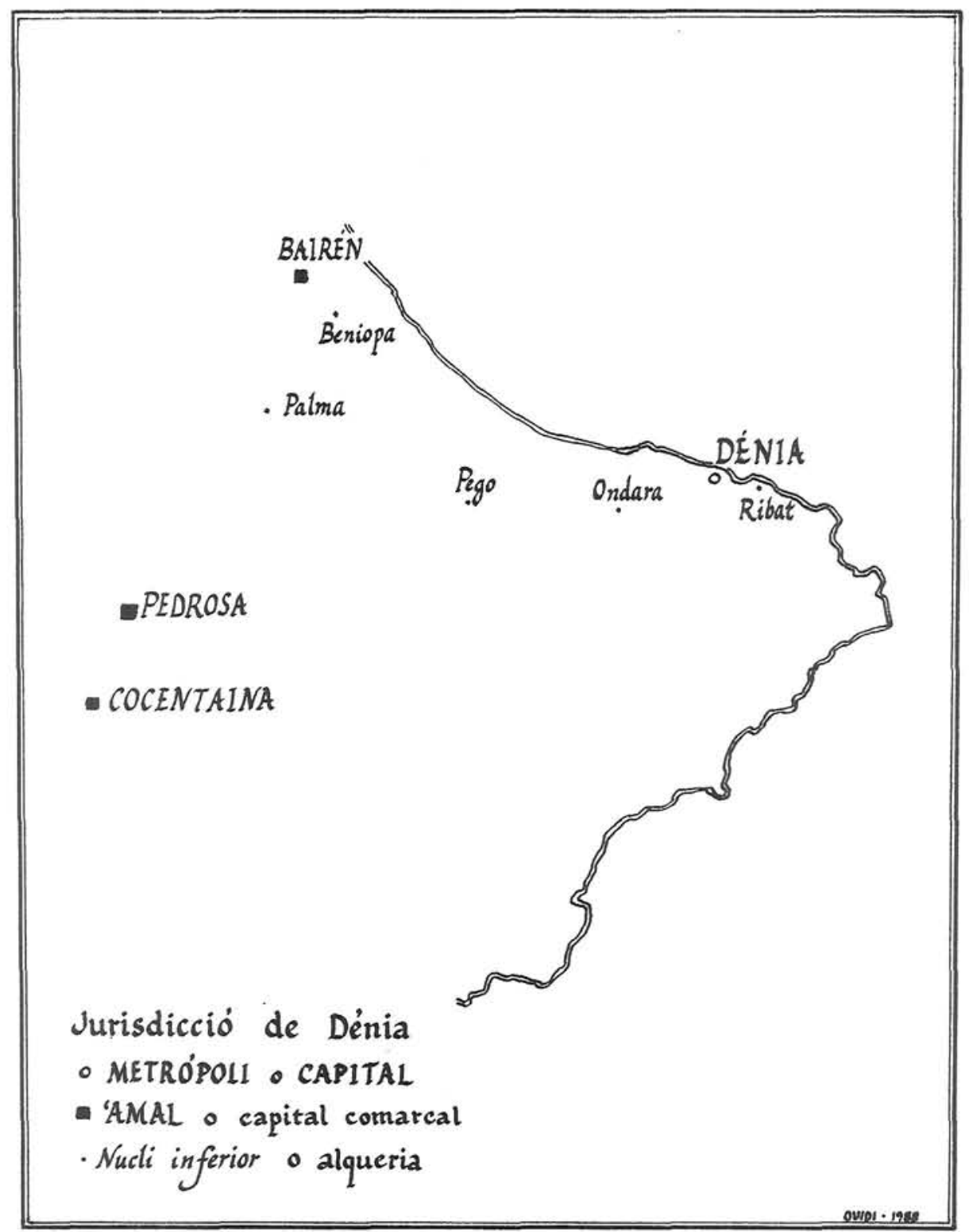


Dénia mantingué per tant la seua jurisdicció habitual des de la taifa del $X \mathrm{I}$ : el sortint muntanyós del Xarc-Al-Andalus, "la quarta illa balear" de l'imperi de Mujàhid, segons l'encertada expressió de María Jesús Rubiera (32).

Ibn-Al-Abbar menciona alguns topònims menors, dependents d'aquests amals de Dénia. De Dénia directament depenia I'alqueria d'Ondara (Undâra min qurà Dâniya amb un biografiat anomenat Al-Undârî CA-1272 CO-621), en època omeia seu de demarcació judicial, que passà amb el poder polític al seu veí port militar de Dénia, en establir-s'hi la capitalitat de la taifa de Mujàhid. Segons Ibn-Al-Abbar, el fill d'aqueix sobirà Icbal-Ad-Daula (lqabâl adDawla) nomenà un cadi "de Dénia i els seus amals» CA-1957 CO-1295. També junt a Dénia hi havia un uribat a la vora del mar de Dénian (Ar-Ribât bi-sîf bahnr Dâniya, que Julián Ribera estudià i situà al paratge de les Rotes (33). També menciona Ibn-Al-Abbar I'alqueria de Pego (Bâgu), dependent directamente de Dénia i d'on era natural un Al-Bâgî AGP (p. 450), i un cadi que era de Luxa («amb pronúncia entre jîm i xîm", és a dir s sonora interdental), identificable amb La Llosa de Camatxo, junt a Pedreguer MU-290.

De l'àmal de Bairén es mencionen dues alqueries: la de Palma (Bâlima, Palma de Gandia, "del juz'» de Bayrân CA-2066 CO-1402) i la de Beniopa (Banî 'Uqba CA-390), ambdues a l'actual comarca de la Safor, que sembla haver estat el límit septentrional de la jurisdicció de Dénia i el seu àmal de Bairén. Més enilà, sembla que començava la jurisdicció de València, amb els amals de Cullera i Alzira, i la jurisdicció de Xàtiva, cap a l'interior.

\section{Les poblacions dependents de Xàtiva}

Xàtiva fou, en època àrab, important metròpoli comercial i cultural, amb una situació estratègica i militar que generalment no es compaginaren amb un paper dominant polític al Xarc-Al-Andalus (34). Ix esmentada en nombroses ocasions en els repertoris biogràfics de savis i magistrats d'lbn-Al-Abbar, que esmenta tres àmals que depenien de Xàtiva: Ontinyent (Untinyân, «àmal de Xàtiva" CA-1289 CO-646, "dels amals de Xàtiva» AGP-2781, que dóna el nom a un Al-Untinyânî CA-1289 (35), Bocairent (Bukayrân, "un dels àmals de Xàtiva" CA-70 i Agres (Agrax, d'on era originari un Al-Agraxî CA-1396 CO-752). S'ha de repetir ací també que els amals que esmenta Ibn-Al-Abbar estan en funció dels seus biografiats i que aquesta llista potser no és exhaustiva.

(32) Veg. M. J. RUBIERA, La Taifa..., p. 58.

(33) J. RIBERA Y TARRAGó, "Un monasterio musulmán en Denia», El Archivo, Dénia, 1, 1886, 67-68; Disertaciones y Opúsculos, Madrid, t. II, 1928, 202-204; "Les Rotes", Almanaque de "Las Provincias», València, 1934, p. 187; Opúsculos Dispersos, Tetuán, 1952, 37-38. Vegeu també J. IVARS PÉREZ, La ciutat de Dénia. Evolució i permanència del fet urbà, Alacant, 1982.

(34) Veg. M. J. RUBIERA - M. de EPALZA, Xàtiva musulmana (segles VIII-XIII), Xàtiva, 1987

(35) J. Ribera corregi I'Untutbân CO-646 (Unxiyân) CA-640 i advertí que aquesta vocalització Untinyân de la grafía àrab 'apropa més a la pronúncia popular "Ontiyén" dels habitants de la regió, més que la grafía catalana o castellana, en «Mislata», Opúsculos Dispersos. Tetuán, 1952, p. 12. També en «Carcaixén, op. cit., ps. 23-25. Veg. C. F. SEYBOLD, MMaccariana I. Onteniente, Cocentaina, Fiñana, Alcaudete en Almaccarim, Revista del Centro de Estudios Históricos de Granada y su Reino, Granada, II, 1912 125-128; M. de EPALZA, "La Vall d'Albaida musulmana», Estudis i Documents, Ontinyent, IV, 1988 , $17-24$. 


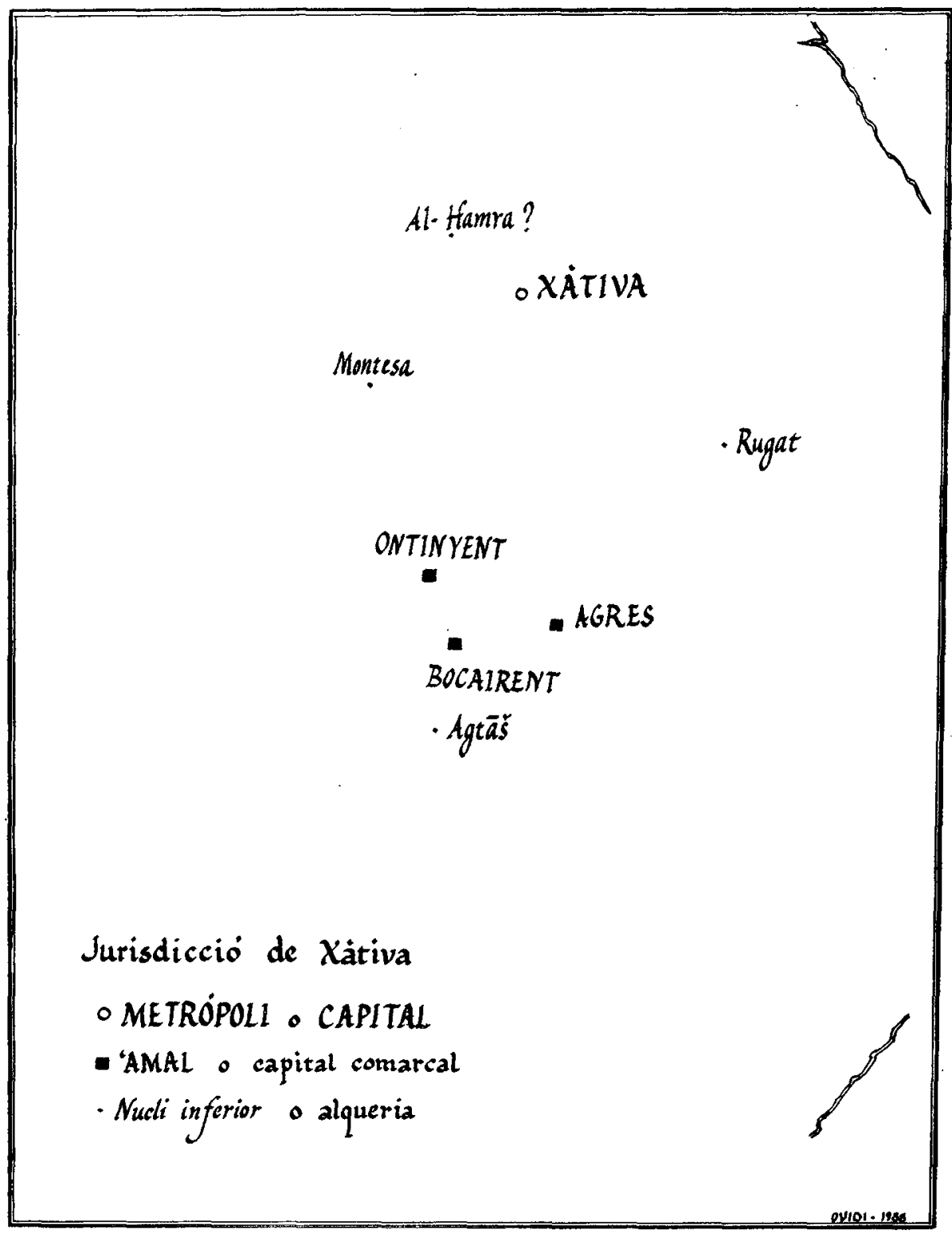


De Xàtiva, metròpoli regional, es diu que és una jafn "parpella», imatge de vall, com si fos un bol o recipient, però que no sembla tenir un significat geogràfic particular, llevat de la imatge que probablement quedà com a qualificatiu.

Ibn-Al-Abbar esmenta diversos topònims menors. Diu que l'alqueria de Montesa (qarya Muntîxa, pàtria dels Al-Muntîxî MU-90 i que no s'ha de confondre amb Mantixa, a Jaén HS-208) "que és prop de Xàtiva" (mușâqaba liXâtiba CA-1195 CO-544). També presenta la biografia d'un anomenat AlHamrawî, que era de l'alqueria d'Al-Hamrà "al nord de Xàtiva» CA-510. L'alqueria de Rugat (Ruqât, "a la Vall d'Albaida» (36) figura com dependent de Xàtiva, "al sud del congost» (qib/î al-fajj CA-2027 CO-1327 MU-202). Hi ha un castell (hișn corregiu edició CA-438) d'Almena (Almâna), dependent també de Xàtiva. També esmenta un "lloc" (mawdi $i^{c}$ ) a l'àmal de Bocairent anomenat Al-Aqtâx CA-70 (37). Finalment, al resum fet per Al-Balfiqî de la seua antologia poètica, esmenta un $|b n-Q a t i ̂|$ de la zona de Dénia, que fa un poema "en el bany de Biar, per les zones de Xàtiva" (hammâm Biyâr min jihât Xâțiba AA 5 p. 18), de difícil localització però que podria ser Biar com la zona més occidental de la jurisdicció de Xàtiva, al costat de la propera Villena, que depenia de Múrcia, però pot ser també un altre lloc encara no identificat.

És evident que en aquesta zona el pes de la metròpoli de Xàtiva dilueix la precisió de les atribucions toponímiques de molts dels seus habitants, difuminats pel seu pas o estada prolongada a la capital. De totes maneres, es pot distinguir una clara ordenació del territori xativenc en dues zones, la de la Ribera del riu Xúquer i la de les zones més muntanyoses i occidentals.

\section{Les poblacions dependents de València}

València, com a metròpoli (khâdira, madîna) però també com a capital política d'una àmplia regió lamb domini constant almenys sobre Dénia i Xàti$v a$, en el segle XIII), té una amplíssima zona de dependències administratives pròpies, a més de l'administració militar d'unes zones frontereres amb els cristians i problemes constants pel sud amb Múrcia. Malgrat tot, la qualificació de les seues poblacions - les més conegudes d'Ibn-Al-Abbar, no cal dir-hosegueix la mateixa regla que s'ha pogut observar en altres regions d'Al-Andalus. Cal estudiar la seua zona, que abraça tota la meitat nord de l'actual País Valencià (al nord d'una "línia» Cullera-Alzira-Bunyol-Requena) en tres cercles, de vegades tangents: els amals o capitals comarcals, les poblacions que envolten la ciutat de València, les zones frontereres o thagrs. Aquesta última zona militar es tractarà en el capítol següent.

(36) Veg. J. RIBERA Y TARRAGÓ, Disertaciones y Opúsculos, p. 212, i C. F. SEYBOLD, «Abbariana I. Agres, Rugat, Ondara, Picasent, en Aben Alabbarn, Revista del Centro..., II, 1912, 191-194.

(37) No és el mateix que Agrax, Agres, àmal independent de Bocairent, segons Ibn-Al-Abbar (Corregiu C. BARCELÓ TORRES, Toponimia..., p. 69, i J. VALLVE BERMEJO, «La división territorial en la España musulmana, II. La Cora de Tudmir (Murcia)", Al-Andalus, Madrid, 37, 1972. 


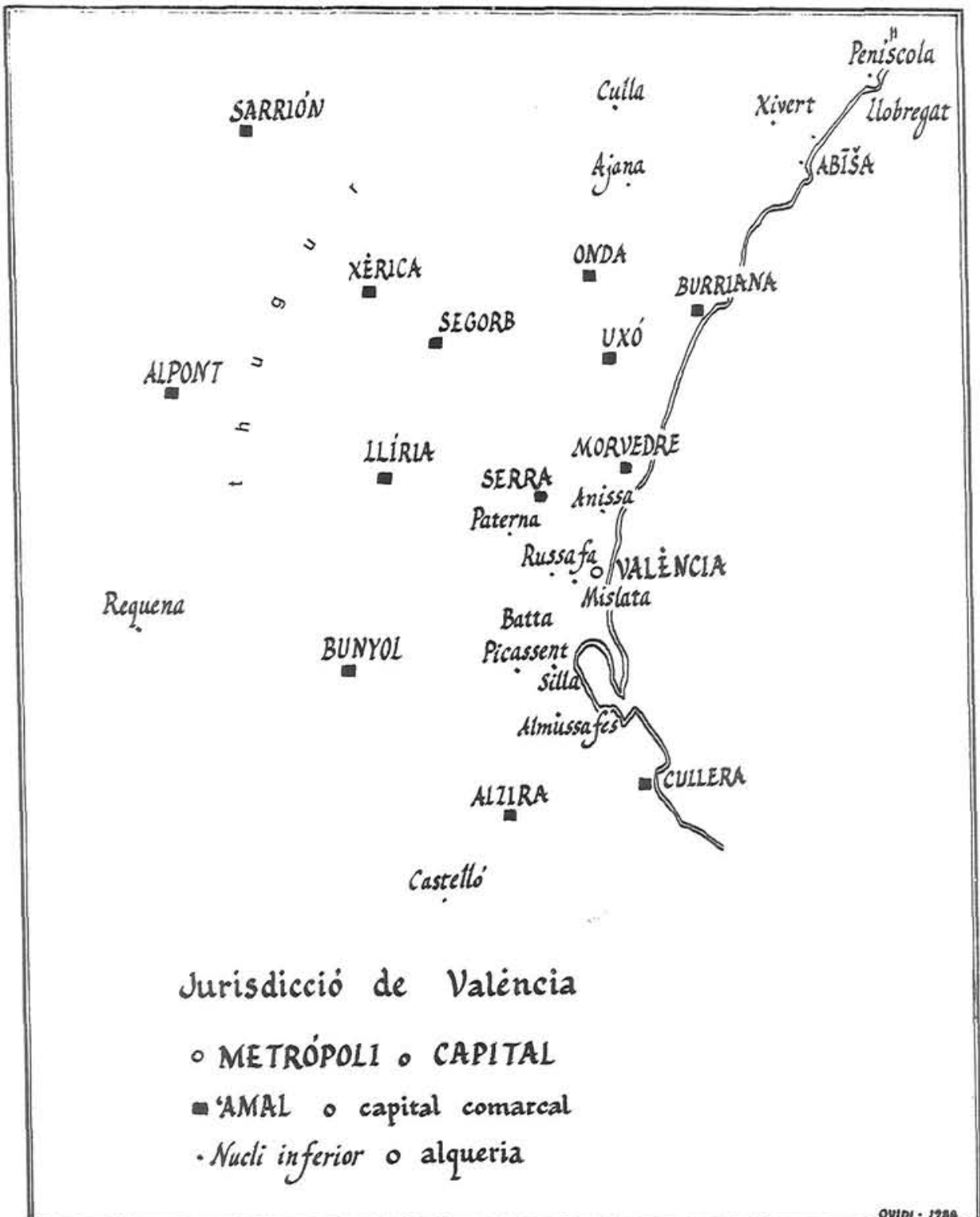


Els amals de València són nombrosos: Alzira (Jazîra Xuqar o Xuqr HS-153 C0-828 i passim), Cullera (Qulyara C0-615 o Qulyayra CA-1266 HS-145, que dóna nom a l'antropònim Al-Qulyayrî CA-265) Bunyol [Bunyûl CA-1517 CO-875 (38)], Llíria (Lirya CO-716 i passim, àmal i cora (39)], Alpont (Albûnt CA-941, que també és thagr CA-1281], Serra [Ax-Xârra CA-1624 CO-978 CO-1922, pàtria d'un Ax-Xârrî (39)], Morvedre (Murbaytar, HS-135 i passim, Sogorb (Xugurb CA-1649 o Xuburb (40), àmal i cora de València CA-185 CA-1366, "de les parts de València» CA-1967), Xèrica [Xâriqa, «àmal de Valèncią" CO-1617 $\mathrm{i}$ "castell dels nobles", qal'c al-axrâf CO-1556, "Xèrica dels noblese, de l'àmal de València» en versió d'Al-Bàlfiqi AA (p. 81) (41)], Sarrión [(Xarriyûn o Xurriyûn CA-207 CA-1215 MU-95 CO-445 CO-564 (42)], Uixó (Xûn AGP-1280 CA-1420 CO-917 CO-778), Burriana (Buryâna, «un dels amals de València» CO-597 i pàtria d'Al-Buryânî CA-1248 CO-838 MU-291), Onda (Unda, passim per ser lloc d'origen d'Ibn-Al-Abbar i els seus familiars; una vegada esmentada com a thagr o zona fronterera MU-28), Abîxa CA-202 CO-1512, prop d'Alcossebre, Orpesa segons Ribera (43), en els thagrs o zones frontereres). Encara que s'afirme d'Albarrasí (Xantamariya Ax-Xarq, «Santa Maria de Llevant", per a distingi-la de la de l'Algarve "o del Ponent") que va dependre de València (44), havia estat ocupada des de feia moltes dècades pels cristians, i quan Ibn-Al-Abbar l'esmenta en la Tàkmila no especifica generalment la seua qualitat d'àmal ni la seua dependència de València. Només s'esmenta en una biografia del Múcjam MU-303. D'altra banda, es dir que Castielfabib (Oastîl al-Habîb) apareix en una biografia d'Ibn-Al-Abbar com «un dels amals d'Albarrasín AGP (p. 408) (45), segons la qual cosa aquesta ciutat seria metròpoli amb amals, com Xàtiva i Dénia. De tota manera, aquesta aparent ambigüitat de les referències és deguda al fet que la jurisdicció musulmana d'Albarrasí ja resultava un anacronisme en els temps d'Ibn-Al-Abbar i que

38) Segons Ibn-Al-Abbar, era la pàtria d'un mallorquí establert a València i anomenat Al-Bunyûli, que en realitat devia ésser del poble mallorqui de Bunyola, que sembla no era conegut per lbn-Al-Abbar i per això el fa originari de Bunyol, "de les nâhiya de València» CO-856, "dels àmals de València» CO-873. Però la seua informació sobre Bunyol pot considerar-se vàlida.

(39) Els personatges oriünds d'aquesta ciutat han estat estudiats per J. RIBERA Y TARRAGÓ, "Abenayad, bibliófilo de Liria". Almanaque de "Las Provincias", 1929, p. 351; Opúsculos..., pp. 15-17

(40) Vegeu J. RIBERA Y TARRAGÓ, Disertaciones y Opúsculos, Madrid, t. I, 1928, p. 214, on identifica el toponim Ax-Xârra. Documentació provant l'equivalència de Xugurb i Xuburb C. BARCELO TORRES, Toponimia..., p. 206

(41) Vegeu J. RIBERA Y TARRAGÓ, "Tribu de Jazrach. Los Jarifes de Jérica», Disertaciones y Opúsculos, Madrid, t. II, 1928, 229-235.

(42) Ribera identifica aquest topònim amb "Sorrió (de Xàtiva)" (Disertaciones y Opúsculos, II, 206), però les referències $\mathrm{d}$, Ibn-Al-Abbar mencionen la seua dependència de València, mai no de Xàtiva (min $a^{\circ}$ âl Balansiya CA-1215 CO-445 CO-508. Potser hi hauria dues ciutats amb un nom semblant,perquè el nom àrab no fa cap dificultat per derivar en qualsevol dels dos (ídem, p. 316 ).

(43) J. RIBERA Y TARRAGÓ, Disertaciones..., I, 214.

(44) Vegeu J. RIBERA Y TARRAGÓ, «Musulmanes de Valencia originarios de Albarracín", Almanaque de "Las Provincias», 1932, p. 283; Opúsculos Dispersos, pp. 31-32, encara que diu "en la época anterior a la Conquista, Albarracín, como Alpuente, dependía del gobierno musulmán de Valencia; pero tal asunto requiere mayor detenimiento para ser tratadon. Es basa segurament en una biografia d'Ibn-Al-Abbar, sobre un magistrat cadi d'Alpont i Albarrasi, dels àmals de Valèncian, després de 545/12 MU-303. Sobre evolució d'Albarrasí i situació del thagr, sobretot en el segle XI, vegeu el mateix Ibn-Al-Abbar HS-129.

(45) És en el suplement d*AGP a una biografia de CO-1867. Vegeu varietat de documentació medieval sobre aqueix topònim C. BARCELÓ TORRES, op. cit., p. 140 El pas de Habïb àrab a Fabib dificultós en casteIlà, no presenta cap dificultat si se suposa que el superestrat romảnic de la zona és el català. 
probablement mai no s'havia aplicat en aquesta zona l'ordenació territorial per amals del govern almohade.

Llíria i Sogorb CA-2082 CO-1418 són qualificades com a cores a més d'amals: ja es justificarà més endavant que aquesta forma de demarcació judicial es dóna en cada àmal, de manera que els 15 àmals dependents de València i, no cal dir-ho, la mateixa metròpoli formaven altres tantes cores judicials.

Aquestos amals tenen alguns llocs menors esmentats accidentalment per Ibn-Al-Abbar: un Alcalà [al-qaka, "fortalesa o castell» AGP (p. 500)], "prop d'Alzira" (bi-maqrab Jazîra Xuqar), i Ajâna que és una alqueria d'Onda AGP (p. 427), mentre que diu que Atzeneta (Zanâta CO-871) depén també d'aquesta ciutat.

Però és l'Horta de València la que més llocs menors proporciona, en les biografies d'Ibn-Al-Abbar, cosa que és lògica pel coneixement major que ell tenia de la zona, per ser aquesta una zona molt poblada i per la seua proximitat als centres d'estudi de la ciutat, on es formaven els «savis» que constitueixen el material dels repertoris biogràfics d'Ibn-Al-Abbar.

Són alqueries dels voltants de València: Bata (Batta «alqueria a l'est o en l'Axarquia de València CA-56 AGP-2191, pàtria d'un Al-Battî (46), AtTawayzât AGP (p. 536), el Puig (Anixxa o Yanîxa CA-1189, conegut per la seua famosa batalla - waqra- en 634/1236, AA (p. 139) AGP-2420 (47), Almussafes [Al Manșaf, amb un ceutí d'origen valencià anomenat Al-Manșafî "el d'Almussafes" AGP-282 CA-929 CO-277 (48)], Silla (Asilla CA-1467 CA-639, "a l'oest de València» CO-823), Picassent (Biqasân, "a l'oest de València» CO-1790, "d'on va prendre el nom un Al-Biqasânî" CA-1231 CO-580 MU-248), Paterna (Bațirna CA-703 CO-51 o Bațârina, pàtria d’un Al-Bațarnî CA-1668), Castelló de I'Albufera (segons Ribera (49), Qaxtiliyûn, pàtria d'un Al-Oaxtiliyûnî CA-705 CO-53), Olocau [Uqawiya CA-754 CO-102, segons identificació discutible de Ribera (50)], Mislata [Manzil 'Ațâ, "posada d'Atà", que

(46) La Dra. María Jesús Rubiera em sugereix que es tracta d'una mala transcripció del topònim d'origen llatí Penna o Penya (Binna en lloc de Batt i del nom d'un conegut poeta valencià Al-Banni, que apareix en fonts cronistiques literàries del XIII. Sobre les relacions de Beni i Penya en la toponímia valenciana, vegeu M. J. RUBIERA - M. de EPALZA, Els noms àrabs..., ps. 54-62.

(47) Vegeu per l'equivalència, C. BARCELÓ TORRES, op. cit., 142. Sembla que Puçol, mantenint restes de la seua primitiva grafia liatina, es va conservar almenys en el nom d'un mallorquí d'origen valencià anomenat Al-Butyühi CA-1500.

(48) Un Al-Múnsafi va ser estudiat per J. RIBERA Y TARRAGÓ, "El Santón de Aimusafes», Almanaque de "Las Provincias", 1930, p. 219; Opúsculos..., 19-22.

(49) "En la Algarbía de Valencia, que en tiempos del rey D. Jaime existía» (Disertaciones..., II, 200). També anomenada Vilanova de Castelló o Castelló de Xàtiva o de la Ribera (C. BARCELO TORRES, op. cit., $139,262)$. Vegeu també J. MARTí SORO, "Los nombres de Villanueva de Castellón a través dé la historia», Crónica del XIII Congreso Nacional de Cronistas de España y XVI Asamblea de Cronistas Oficiales del Reino de Valencia, València, 1988, 247-266.

(50) Vegeu J. RIBERA Y TARRAGÓ, "Abenayad...", p. 16, encara que l'etimologia d'Olocau és molt diferent, segons opinió reonada d'E. TERÉS, "Al-cAqaba...", recollida por C. Barceló lop. cit., p. 187, Olocau de Carraixet). Queda doncs en dubte la identificació d'aquesta alqueria de l'àmal de Llíria, segons Ibn-Al-Abbar. 
s'esmenta com a "una de les alqueries de València», min qurà Balansiya, i pàtria d'uns Al-Manzilî CO-1924 AGP-2410 (51)].

Un lloc menor dependent de València, Abadû, no se l'esmenta com a alqueria ni tampoc Russafa (Rusâfa o Ruṣâfa, "la Russafa de València» AGP-2507 CA-946, per a distingir-la dels seus antecedents de Còrdova i Síria (52); dóna I'antropònim Ar-Rușâfí CA-1416 CO-294 AA (p. 56). De prop de Russafa era un valencià, de Malilla (53). S'esmenta, en el resum d'Al-Bàlfiqui, una incursió o ràtzia contra els cristians, a Albarrasí, amb conquesta d'un castell (hișn Xazâla) i atac cristià d'un altre [hiṣn Al-Mîl, aquest últim "de les zones de València" (min nawâhî Balansiya AA (p. 143)].

\section{Les regions frontereres amb els cristians}

Molt específic dels espais governats per I'Islam és la consideració particular que mereixen els territoris "fronterers" o extrems, on acaba el govern islàmic, en general. Aquesta consideració, política i militar, no prové sols de la situació perillosa d'aquestes regions, pels possibles atacs dels enemics nomusulmans. Són territoris on és més fàcil complir amb el deure de la "Guerra Santa", "l'esforç virtuós en el camí de Déu», (al-jihâd fî sabîl Allâh), un dels preceptes teòricament més importants de I'Islam, deure de solidaritat col.lectiva.

Les costes marítimes, sempre subjectes a possibles atacs navals, i les terres de "l'Occident lunyà» (el Màgreb i Al-Andalus) han tingut una importància particular, tradicionalment, per al compliment d'aquesta obligació religiosa. A la Península Ibèrica, a mesura que els territoris cristians es feien com més anava més independents i indòcils enfront de l'autoritat cordovesa (54), es van anar configurant unes "zones fronteres de l'Islam", que els historiadors europeus anomenen «Marques», per similitud amb els territoris que s'anomenaven així a l'Imperi Germànic. Però com que la noció fonamental és molt diferent, crec que s'hauria d'utilitzar un arabisme, tant en català com en castellà, derivat de la paraula àrab que designa aquestos territoris fronterers: thagr i thagrs, en català, i zagr o zagres, en castellà (dels mots àrabs transcrits thagr, plural thugûr, que van donar en castellà antic "tagareno» $\mathrm{i}$ "zegri»).

Els thagrs tradicionals d'Al-Andalus abraçaven els territoris musulmans més septentrionals: el Thagr superior, amb capital a Saragossa, comprenia les valls mitianes de l'Ebre, des de les actuals Rioja i Ribera navarreses, fins

(51) Ho va demostrar J. RIBERA Y TARRAGÓ, «Mislata», Almanaque... 1928, p. 175; Opúsculos..., pp. 11-13.

(52) Vegeu E. TERÉS SÁDABA, "Textos poéticos árabes sobre Valencia", Al-Andalus, Madrid, XXX, 1965. 291-307.

(53) Segons l'apèndix d'AGP, p. 458, a biografia de C0-1850. Seria l'alqueria cristiana de Malilla (veg. C. BARCELÓ TORRES, op. cit., p. 177).

(54) Ja he exposat aquesta teòrica sobirania que Còrdova es donava sobre els sobirans cristians i llurs súbdits (M. de EPALZA, "Attitudes politiques de Tunis dans le conflit entre Aragonais et Francais en Sicile autour de 1282n, La società mediterranea all'epoca del Vespro (XI Congresso di Storia della Corona d'Aragonal, Palermo, vol. 2, 1983, 579-601. 
L'ORDENACIO DEL TERRITORI DEL PAIS VALENCIA ... I Epalza

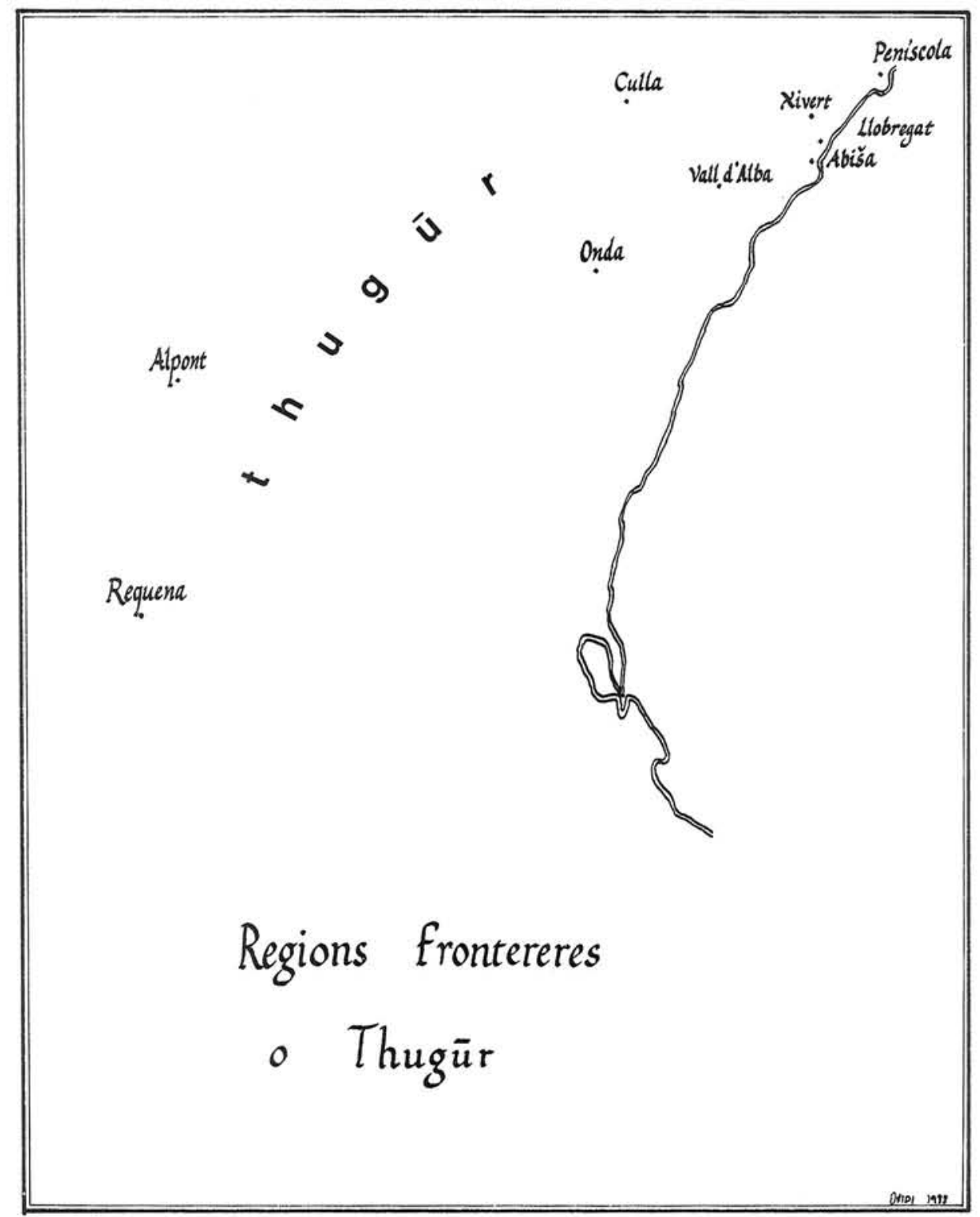


a la zona d'Ósca (55); els thagrs orientals (ath-thugûn ax-xarqiyya), que comprenien les regions de Lleida, la vall inferior de l'Ebre, les altures de Terol, Tarragona i Tortosa (56); el Thagr mitjà, entre Medinaceli i Talavera, amb centre a Toledo i Madrid; el Thagr inferior, des d'Alcàntara i Mèrida fins a l'Atlàntic.

Però aquesta organització dels territoris fronterers del segle $X$ va sofrir variacions, segons les conquestes cristianes. En el segle XV, per exemple, el thagr del regne nassarita de Granada estava al nord de l'horta de Granada, al coll anomenat, per això, de Zegrí. En el segle XIII, el territori valencià constituia la zona més septentrional del govern musulmà, després de les conquestes del XII de les valls de l'Ebre i de l'altiplà manxec. Per això té un especial interés la consideració dels thagrs valencians, segons Ibn-Al-Abbar.

En els escrits d'Ibn-Al-Abbar es juxtaposen dues realitats: els thagrs del segle $X$, en les seues quatre parts, quan parla de realitats anteriors al XII i a la caiguda de les valls de l'Ebre, especialment les poblacions dels "thagrs orientals» (Daroca CA-1989, Calanda, Balaguer, Tortosa, Ciurana CA-1250...) i els "thagrs de València" de la seua època, que són els que particularment interessen en aquest treball. Són territoris especialment organitzats en funció de la guerra, amb els seus "exèrcits del thagr" (ajwâd ath-thagr HS-145).

Les poblacions d'aquestes regions frontereres dependents de València, que apareixen en Ibn-Al-Abbar, són les següents: Requena (Rakâna, "dels thagrs de Valéncia» min thugûr Balansiya CA-813 CO-161 CO-1564, pàtria d'un Ar-Rakânî AGP-2327), Alpont (Albûnt, thagr i àmal alhora CA-1281, "del thagr de València" "thagr de València" AGP-2598, "dels thagrs de València" AGP-2206 AGP-2332, amb el qualificatiu militar de «castell» - hiṣn i qalla-; allí "va morir màrtir" (ixtahada) un lleidatà, Ibn Qabrûn, magistrat de Xàtiva i València, "en la batalla d'Alpont, del thagr oriental", en 508/1114/5 AGP-2755), Onda (sols una de les moltes vegades que s'esmenta aquesta ciutat, origen familiar d'lbn-Al-Abbar, es diu que és thagr: un magistrat era empresonat "a Onda, dels thagrs de València» MU-128), Peñíscola (thagr Binixkula CCO-1802, "davant de Tortosa", muhâdiya li-Turțuxa, és a dir, probablement, que depenia de Tortosa, abans de la seua caiguda; és pàtria d'un Al-Binixkulî, "dels thagrs de València" MU-247), Abîxa [àmal i thagr, "un dels thagrs de València" CA-1494 CO-850, "un dels thagrs orientals de València" CA-2176 CO-1512 (57)], Xivert (Xubârt, "dels thagrs de València» CA-533, pàtria d'un Ax-Xibârtî CA-2044 CO-1380), La Vall d'Alba (Billu Alba, "en el thagr", pàtria d'un Al-Bilâlbî CA-249), Culla (Kulaya, "dels thagrs orientals" CA-941 CO-289), Baxja [uun dels thagrs orientals» AGP (p: 445)] i Llobregat [Lubriqât, dependent d'Abixxa CA-2176 CO-1512 (58)].

(55) Vegeu M. de EPALZA, «El Islam aragonés, un islam de frontera», Turiaso, Tarazona, Vil, 1987, 9-21.

(56) Vegeu $M$. de EPALZA, "Tortosa, un lloc estratègic a Al-Andalus", D(T), Tortosa, 2, 1987, 13-15.

(57) Vegeu supra, nota (20).

(58) Possiblement Torreblanca (vegeu C. BARCELO TORRES, op. cit., p. 215). Sobre el topònim, vegeu E. A. LLOBREGAT, "La perduración de un topónimo de la Vía Augusta: Lubricatum/Rahal Al-Lobrecati/Turris de Lupricaton, Sharq Al-Andalus. Estudios Árabes, Alacant, 1, 1984, 103-107. 
També s'hi esmenta un valencià originari del thagr de València, en general CA-1820, i d'un lleidatà que va morir "màrtir» en la batalla d'Al-Bûrt (zels Ports? MU-145) (59). Del castell de Montornés (hiṣn Muțurnix HS-145) diu Ibn-Al-Abbar - referint-se a un biografiat del segle XII, desterrat- que era a la frontera entre Tortosa i Barcelona (és un error, probablement de copista, perquè es troba a les muntanyes entre Orpesa i Cabanyes) i que era unna de les fortaleses més inassequibles de València" (min amna ${ }^{c}$ macâqil Balansiya), el qual és cert, fins ara.

Aquesta enumeració de llocs "fronterers" indica bé on consideraven els àrabs valencians del $\mathrm{s}$. XIII que eren les regions de possibles atacs cristians: les regions occidentals de Requena i Alpont, com a entrades des de Castella i Aragó a les planes valencianes, i la regió costanera septentrional, porta oberta des de Catalunya cap a la costa de les actuals comarques septentrionals i centrals del País Valencià. És un poc estrany o inexplicable per a nosaltres que no s'hi esmentaren com a thagrs les poblacions de la gran via de possibles atacs dels aragonesos des de Terol a València: els amals d'Albarrasí, Sarrión, Xèrica (encara que es diu que aquesta és "castell», qaka CA-127 CA-45 C0-1556 CO-550 Mu-12), Sogorb, Uixó i Morvedre (60).

Tot i que depenien de València, com les altres regions estudiades al capítol anterior, aquestes regions «frontereres» mostren una ordenació del territori valencià amb unes característiques molt específiques dels començaments del segle XIII.

\section{L'ordenació judicial del territori valencià}

Ja s'ha indicat, en estudiar la nomenclatura, per què la denominació administrativa de cora (kûra, plural kuwar) indica en Ibn-Al-Abbar una unitat de jurisdicció judicial. Era un canvi de la utilització anterior d'aquest mot, en l'epoca omeia, quan significava una gran demarcació jurisdiccional o un mot de demarcació geogràfica també de gran magnitud. A falta d'estudis més detallats sobre aquesta evolució terminològica, apuntem la hipòtesi que el doblet camal-kûra, jurisdicció administrativa-militar i jurisdicció judicial-civil forma part de les reformes introduïdes a Al-Andalus pels sobirans de Marràqueix, a la caiguda dels regnes de taifes, almoràvits de la fi del segle XI i, sobretot, almohades de mitjan segle XII. A aquesta doble xarxa d'ordenació territorial basada en les ciutats correspon una doble xarxa de funcionaris: els emirs, els walís, els àmils i els alcaids, de la jurisdicció militar (Ibn-Al-Abbar sols menciona un wâli almoràvit de València CO-1122 i un altre que va nomenar un cadi SA-75; als sobirans dels regnes de taifa del segle XI i XII els anomena simplement "senyor o amo de" șâhib, per exemple "el senyor de Dénia»

\footnotetext{
159) Per la localització de la província àrab d'Al-Bürt, en territoris de Tortosa, Tarragona i Barcelona, vegeu F. HERNÁNDEZ JIMÉNEZ, "Estudios de geografía histórica española. IX. El Monte y la Provincia «del Puerton, Al-Andalus, Madrid-Granada, XVH, 1952, 319-368.

(60) Ja ho va notar M. C. BARCELO TORRES, Minorias islámicas en el País Valenciano. Historia y dialecto, Madrid, 1984, 166: "Por otro lado, los valles del Palencia y el Millars no parece que fueran lugares
de acceso desde Teruel a Valencia».
} 
CO-1295) i els cadis i altres magistrats, predicadors i kàtibs, docents i la resta de funcionaris que formaven la classe dels alfaquíns, d'allò que podríem anomenar aproximadament «administració civil».

Ací no ens ocuparem de definir l'entramat i les funcions d'aquestes dues classes de càrrecs, però les esmentem almenys per aclarir un poc la situació del cadi (61), i, sobretot, per a presentar des del punt de vista d'aquesta autoritat judicial l'ordenació del territori valencià d'Ibn-Al-Abbar, tot just abans de la conquesta cristiana.

Ibn-Al-Abbar sols menciona expressament tres cores en territori actualment valencià: Elx (CA-1398; sobre un magistrat de qui es diu que «va ser nomenat cadi d'Oriola [...] d'Elx i d'altres cores de Múrcia» CA-1550 CO-518), Llíria («va ser nomenat cadi a Llíria i d'altres cores» CA-1456 CO-822) i Sogorb ("una de les cores» de València, min kuwar CA-2082). Però Ibn-Al-Abbar menciona a més molts altres llocs com a seus de cadis, la qual cosa pot ferlos equivalents a les cores expressament esmentades. Aquestos llocs són: València, Xàtiva, Dénia, Oriola, Elx, Cocentaina CA-1346, Alzira, Llíria, Alpont, Morvedre CO-753, Xèrica i Onda. També esmenta d'altres poblacions com a llocs d'altres magistratures, com la de qâdî al-ahkâm: València, Xàtiva (en "alguns jihât de Xàtiva» CA-2177, cosa que indicaria una organització inferior, la de les cores dependents les unes de les altres, potser), Morvedre, Alpont, Llíria, Xèrica CO-1556. Aquestes llistes, que coincideixen enterament amb les de les metròpolis regionals (Múrcia, Dénia, Xàtiva, València) i els amals comarcals, ens permeten de suposar, amb tota lògica, que a cada ciutat amb àmil corresponia una cora amb cadi.

La metròpoli tindria així unes cores sufragànies, com tenien amals: es parla de l'exili d'un jutge a "Sogorb (Xaburb), una de les cores de València», d'un cadi "de Dénia i els seus amals» (en temps del regne de taifa del segle XI CA-1957 CO-1295) i d’un cadi que estenia la seua jurisdicció a "Oriola, Múrcia i tots els jutges dels restants amals seus [de Múrcia]», en aquestes dues expressions la confusió entre cores i amals és fàcilment explicable, precisament perquè ambdues denominacions abastarien la mateixa xarxa de poblacions. Un cadi nomenat pels almoràvits "cadi de Xarc-Al-Andalus" exercí "durant molt de temps" potser en tota la regió, perquè després se'n va a Marràqueix el 521/1127/128 i torna a Al-Andalus ja com a cadi de llocs particulars, Múrcia i Almeria MU-116. Expressions com ufou nomenat cadi d'algunes cores» CA-1880 o "en nombroses cores de València i d'altres llocs» CA-2117 s'han d'entendre «successivament» i no com a jurisdicció superior a la cora com a unitat jurisdiccional judicial: vegeu, per exemple, «en nombroses cores de la seua terra [València]» CA-1457 CO-813 o també «en algunes cores llevantines» CA-1471 CA-820 CO-827 CO-168, o "en moltes cores" AGP-2770.

(61) Sobre les funcions del cadi escriu Ribera: "Traduzco alcadi, que significa juez, por alcalde, porque los jueces habian adquirido ya entonces funciones políticas y gubernamentales», que podriem dir administratives («La Plaza del Alcalde (Ránbatolcádi)», Almanaque..., 1926; Disertaciones..., p. 322) i "por ser la palabra derivada de la voz arábiga» (Disertaciones..., p. 2161. Crec que més que un alcalde d'un municipi actual, ho seria d’una comarca. Vegeu també supra, nota (15). 


\section{Conclusions}

Basant-se en les qualificacions dels noms de lloc de l'actual Comunitat Autònoma Valenciana que fa en les seues biografies Ibn-Al-Abbar (1199-1260), es pot esbossar una ordenació del territori centrada en les ciutats: les capitals regionals (Múrcia, Dénia, Xàtiva, València), les capitals comarcals (els amals) i els llocs menors (especialment les alqueries o pobles). Les cores corresponen a una demarcació judicial paral.lela als amals, amb els seus cadis titulars. La situació militar del territori valencià al segle XIII obliga a una ordenació especial dels "territoris fronterers" o thagrs de València (Requena, Alpont, el nord de l'actual província de Castelló\}. Aquest treball vol contribuir a subratllar el caràcter urbà de la societat àrab valenciana i a especificar segons els períodes i les fonts d'història àrab, l'ordenació del territori abans de la conquesta cristiana del segle XIII.

\footnotetext{
(*) Agraesc a Ovidi Carbonell la confecció dels mapes, i al Servei de Normalització Lingüística de la Univer-
} sitat d'Alacant la traducció i l'ajut per a la correcció d'aquest text. 